\title{
The Association between Patellofemoral Congruence and Functionality of the Knee Joint in Patients with Chondromalacia Patella
}

\author{
Kondromalazi Patella Tanılı Hastalarda Patellofemoral Uyum ile Diz Ekleminin \\ Fonksiyonelliği Arasındaki İlişki \\ Fatih Hakan Tufanoğlu $^{1}$ (D) Fatih Bagcıer ${ }^{2}$
}

$\underline{0 ̈ z}$

\begin{abstract}
Amaç: Kondromalazi patella, anterior diz ağrısı ile karakterize olan patellar kartilaj dejenerasyonudur. Bu çalışmada anterior diz ağrısı ile polikliniğimize başvuran ve manyetik rezonans görüntüleme ile kondromalazi patella (KMP) tanısı koyduğumuz hastalarda patellofemoral uyum ile diz fonksiyonelliği arasındaki ilişki değerlendirildi.
\end{abstract}

Araçlar ve Yöntem: Çalışmamız tek merkezli kesitsel çalışma olarak dizayn edildi. Hastaların sosyodemografik özellikleri kaydedildi. Çalışmamız 36 hastanın 48 diz manyetik rezonans görüntülemesi (MRG) üzerinde gerçekleştirildi. Hastalar; Modifiye Outerbridge skalasına göre dört evreye, erken (Evre 1-2) ve ileri evre KMP (Evre 3-4) olarak iki gruba ayrıldı. Hastaların fizik muayene bulguları (Clark testi, patellar kompresyon testi, patellar tilt testi, J bulgusu), fonksiyonellik düzeyleri (WOMAC) ve MRG görüntüleme parametreleri değerlendirildi.

Bulgular: Gruplar arası kıyaslamada ileri evre grubunun yaş ortalaması ve ağrı süresi istatistiksel olarak anlamlı düzeyde yüksekti $(\mathrm{p}<0,001)$. MRG parametrelerinde gruplar arası farkl11ık tespit edilmedi ( $p>0.05)$. Erken evre grubunda 3 hastada patella alta, 5 hastada patella baja, ileri evre grubunda 4 hastada patella alta, 4 hastada patella baja tanısı konuldu. Fonksiyonellik parametreleri kıyaslandığında ileri evre grubunda, erken evre grubuna kıyasla istatistiksel olarak anlamlı düzeyde yükseklik tespit edilmiş̧ir $(\mathrm{p}<0,001)$.

Sonuç: KMP hastalarında ileri evrelerde hastaların fonksiyonelliği azalmaktadır. MRG parametreleri, erken evre ve ileri evre KMP hastaları arasında farklılık göstermemiştir. Patellofemoral eklemde subjektif yakınmalarla, klinik ve görüntüleme bulguları korelasyon göstermediğinden bu konuda daha geniş popülasyonun dahil olduğu çalışmalara ihtiyaç duyulmaktadır.

Anahtar Kelimeler: fizik muayene; kondromalazi patella; manyetik rezonans görüntüleme

\section{ABSTRACT}

Purpose: Chondromalacia patella (CMP) is characterized by anterior knee pain with patellar degeneration. Our study was undertaken to assess the association between patellofemoral congruence and knee functionality in patients with anterior knee pain who were diagnosed with CMP based on magnetic resonance imaging. (MRI)

Materials and methods: The study was designed as a single-center, cross-sectional study. The sociodemographic of the patients were recorded. 36 patients with 48 knee MRI examinations were involved and grouped based on the Modified Outer bridge Grading system: Early-stage (Stage 1-2) and advanced-stage CMP (Stage 3-4). Physical exam findings (Clark's test, patellar compression test, patellar tilt test, J sign), level of functionality (WOMAC), and MRI parameters were evaluated.

Results: The mean age and duration of the pain were significantly higher in patients with advanced stage CMP (p > 0.05) (Table 3). The two groups did not differ in terms of Insall-Salvati index and patellar translation $(\mathrm{p}>0.05)$. Patella alta and patella baja were detected in 3 and 5 patients with early-stage CMP and in 4 and 4 patients with advanced-stage CMP respectively. $(\mathrm{p}<0.001)$.

Conclusion: Advanced stage CMP is associated with reduced functionality. However, patients with early or advanced stage CMP did not differ significantly with regard to MRI. Since clinical and imaging findings are not correlated with subjective complaints regarding patellofemoral joint, studies involving larger populations are warranted.

Key Words: magnetic resonance imaging; patellar chondromalacia; physical examination 


\section{INTRODUCTION}

Chondromalacia patella (CMP) is a condition characterized by anterior knee pain accompanied by the softening, fraying, or ulceration of the cartilage on the posterior patellar surface. ${ }^{1}$ This condition is associated with clinical manifestations such as pain, swelling, and retropatellar crepitation and is more likely to occur in younger individuals and females. ${ }^{2} \mathrm{CMP}$ is thought to be caused by overloading on the lateral patellar facet due to misalignment as well as by the shear forces on the central ridge of the patella. This leads to underloading on the medial patellar facet, which may lead to softening of the cartilage. Other etiological factors include prolonged immobilization, arthroscopic surgery, or direct trauma to the anterior knee. The diagnosis of CMP is based on physical and radiological examination. Although a variety of physical examination tests have been described, each method provides a certain level of sensitivity and specificity. The definitive diagnosis requires an arthroscopy. ${ }^{3-5}$

Conventional radiography or computed tomography does not suffice to accurately identify the cartilage pathology. On the other hand, magnetic resonance imaging may provide valuable information not only on the bone and surrounding soft tissues, but also on the cartilage tissue ${ }^{6-7}$ which allows ruling out other common causes of anterior knee pain such as medial synovial plica, osteochondral fractures, patellar retinacular ligament injury, free objects, and tendinitis..$^{8-9}$ Conservative management is generally successful and includes measures such as activity modification, rest, nonsteroidal anti-inflammatory drugs, exercises aimed at strengthening the quadriceps muscles, patellofemoral joint mobilization and patellar kinesiotaping. ${ }^{10-11}$ Acquired or developmental differences in the congruency and anatomy of the patellofemoral joint may lead to an inappropriate distribution of the mechanical load on the patellofemoral joint, leading to chondrosis, early osteoarthritis, synovial proliferation, and subchondral cystic or sclerotic changes associated with pain as well as the fat pad impingement syndrome. ${ }^{12}$ As a result of the mechanisms stated above, the clinical significance of the differences in the patellofemoral anatomy and patellofemoral misalignment have been underscored in the literature in the context of their contribution to the identification of proper management strategies. ${ }^{13}$ In this study, we aimed to examine the association between the severity of chondromalacia patella, patellofemoral congruency, and knee functionality as well as to assess whether the results of physical examination findings vary according to the stage of the chondromalacia patella in a group of patients diagnosed with patellar chondromalacia.

\section{MATERIALS AND METHODS}

A total of 36 patients with 48 knee MRI examinations presented to the corresponding author's Physical Medicine and Rehabilitation outpatient clinic, between July 2019 and August 2019 with the complaint of anterior knee pain and diagnosed as having chondromalacia patella based on magnetic resonance imaging were included. 12 patients had bilateral knee examinations while 24 patients had a unilateral examination. All patients provided written informed consent. The study protocol was approved by the Ethics Committee of the Kars Kafkas University Faculty of Medicine, (Decision date: 26.06.2019 Approval no: 80576354-050-99/179), and the study procedures were carried out in accordance with the principles set forth in the Helsinki Declaration.

Inclusion criteria were as follows: (1) Age between 18 and 55 years, (2) presence of anterior knee pain, (3) negative McMurray test, Apley compression-distraction test, Valgus-Varus stress test, and anterior-posterior compartment test, (4) adequate education for comprehending and filling out the test forms used for study purposes.

Exclusion criteria were a history of lower extremity surgery, major trauma, neuromuscular disease, pregnancy, cancer, genu varus valgus deformity, intra-articular injections, medial compartment arthrosis, and rheumatoid disorders. Based on magnetic resonance imaging findings and Outerbridge Grading System, two groups with 24 patients in each were identified as those having early stage (Stage 1-2) and advanced stage (Stage 3-4) CMP.

Assessment of demographic characteristics: Age, gender, height, body weight, occupation, and duration of disease were recorded for each patient. 
Results of physical examination: Clark's test, patellar compression test, patellar tilt test, and $\mathrm{J}$ sign were recorded as positive or negative. A goniometric measurement was performed for the knee flexion angle. Physical examinations were performed by a physical therapy and rehabilitation specialist with 5 years of experience.

Clark's test: While the examiner's hand exerts pressure on the superior pole of the patella the patient is asked to actively contract the quadriceps muscle. It is assumed positive if the patient experiences pain.

Patella tilt test: With the knee at full extension and quadriceps muscle relaxed, examiner tries to lift up the outer edge of the patella using his thumb medially. If the lateral retinaculum is tight, the outer edge of the patella stays below the horizontal line, the examiner may not be able to lift the patella.

Patella compression test: While the patient is in supine position and the tested knee flexed to $20^{\circ}$, the patella compressed against the femoral groove. When the participant reports pain, the test is recorded as positive.

J sign: Patellar lateral deviation observed with the patient supine or seated and the knee extended from a flexed position.

\section{Western Ontario and McMaster Universities}

Osteoarthritis Index (WOMAC): This tool examines the following domains: pain (5 items), stiffness (2 items), physical function (17 items), social functions (7 items), and emotional functions (10 items). A score between 1 and 5 is given for each item (1: none, 2: mild, 3: moderate, 4 : severe, 5 : very severe), and the sum of the scores within each domain provides a total score for that domain. ${ }^{14}$ Higher score correlates with more pain, more stiffness, and less functionality.

Modified Outer bridge Classification: Reflects the severity of cartilage alterations on MR images.

Grade 0: Normal cartilage

Grade 1: Signal intensity alterations with an intact surface of the articular cartilage
Grade 2: Partial thickness (less than $\% 50$ of the cartilage thickness) defect of the cartilage

Grade 3: Fissuring, ulceration of the cartilage to the level of the subchondral bone (> $\% 50$ of the cartilage thickness)

Grade 4: Exposed subcondral bone

Magnetic resonance imaging measurement parameters: Magnetic resonance images were obtained using a 1.5 Tesla device (Hitachi Medical Corporation, Tokyo, Japan) with the patient in supine position and the knee extended. All images evaluated by a radiologist with 5 years of experience. Coronal proton density fat-saturated FSE (TR/TE:1906/12, FOV:18*18, Section thickness: 4.3 mm Matrix: 320*288), sagittal T1 SE (TR/TE:432/11, FOV:18*18 Section thickness: $4.2 \mathrm{~mm}$ Matrix:320*256), sagittal proton density FSE (TR/TE:1753/12, FOV:18*18, Section thickness: $4.2 \mathrm{~mm}$ Matrix: $320 * 280$ ), and axial proton density fat saturated FSE (TR/TE:2125/36, FOV:18*18, Section thickness: $4.4 \mathrm{~mm}$ Matrix:320*320) sequences were obtained. Settings in all sequences included width and level values of 1000 and 500, respectively, with a section distance of $4 \mathrm{~mm}$. For each knee, the stage of chondromalacia was first determined using the Modified Outer bridge Grading (Stages 1-4), followed by the measurements of trochlear sulcus angel, sulcus depth, lateral patellofemoral angle, patellar translation, and Insall-Salvati index measurements. InsallSalvati index was measured in sagittal views, while the axial views were used for other measurements.

Trochlear sulcus angle: The sulcus angle is the angle formed between lines drawn from the center of the deepest portion of the trochlea to the medial femoral condyle and to the lateral femoral condyle (Figure 1). In axial images obtained at a knee flexion angle of 30-45 degrees, the sulcus angle is approximately $140^{\circ} .{ }^{15}$

Sulcus depth: This is represented by the distance between the tips of the medial and lateral trochlear facets to the deepest portion of the trochlear sulcus (Figure 1). A normal value is above $5 \mathrm{~mm}$, with values below $5 \mathrm{~mm}$ suggesting hypoplasia, and below $3 \mathrm{~mm}$ suggesting dysplasia. ${ }^{15}$

Lateral patellofemoral angle: The measurements were performed in axial views, in which the trochlear sulcus was deepest and patella was widest. It is the angle that is 


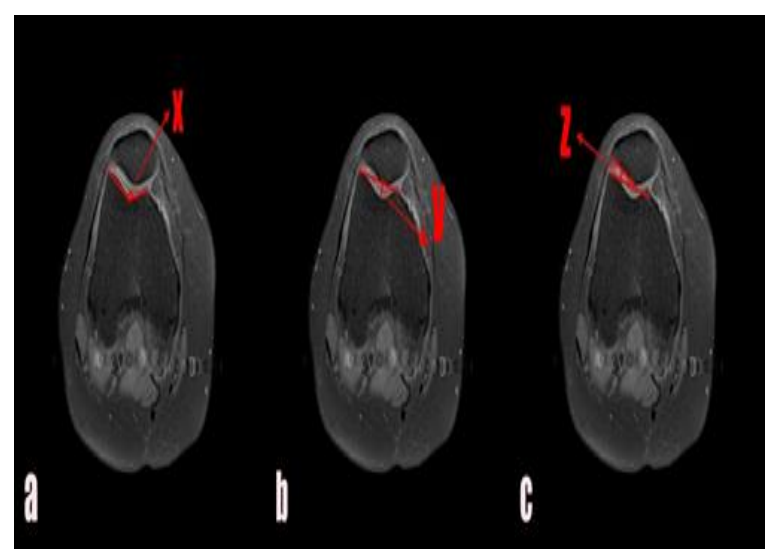

formed by a line drawn parallel to the bony lateral patellar facet and a line that is tangential to the anterior portion of the condyles (Figure 1). A normal value is 8 degrees or higher. ${ }^{15}$

Figure 1. Measurements of trochlear sulcus angel (a), sulcus depth (b), lateral patellofemoral angle (c).

$\mathrm{x}$ : Angle formed between lines drawn from the center of the deepest portion of the trochlea to the medial femoral condyle and to the lateral femoral condyle y: Distance between the tips of the medial and lateral trochlear facets to the deepest portion of the trochlear sulcus z: Angle that is formed by a line drawn parallel to the bony lateral patellar facet and a line that is tangential to the anterior portion of the condyles.

Patellar translation: It is the distance between the parallel lines passing through the medial patellar corner and the most anterior portion of the medial condyle that are perpendicular to the posterior femoral condyle (Figure 2).

A normal value is below $3 \mathrm{~mm}{ }^{16}$

Insall Salvati Index: It is the ratio between the length from the most proximal part of the patella (excluding osteophytes and enthesophytes) to the most distal and anterior tip and the length from the distal tip of the patella and the attachment point of the patellar tendon on the tibial tuberosity. ${ }^{17}$

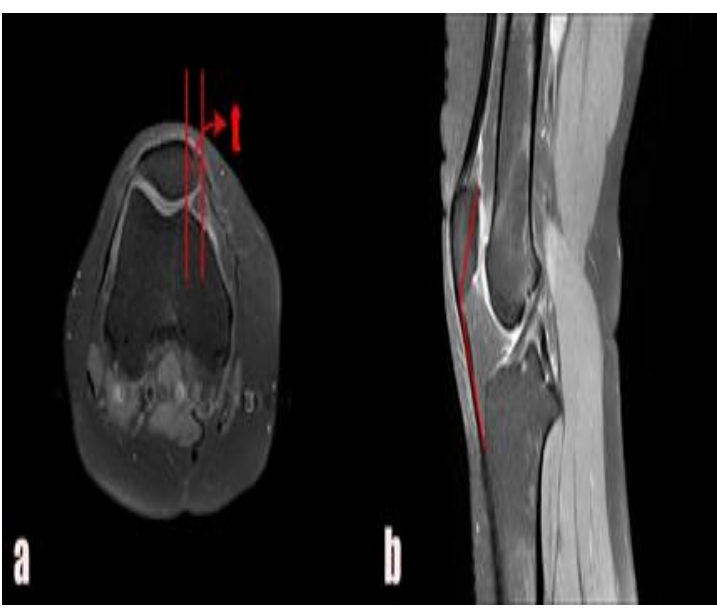

Figure 2. Patellar translation shown by $\mathrm{t}(\mathrm{a})$, and Insall-Salvati index measurements (ratio of the patella tendon length to the length of the patella) (b).

t: Distance between the parallel lines passing through the medial patellar corner and the most anterior portion of the medial condyle that are perpendicular to the posterior femoral condyle.

\section{Statistical analysis}

Data was presented using frequency and percentage for categorical variables. To compare the categorical data in terms of other categorical properties, chi-square and Fisher's exact tests were used. Two groups were compared with regard to measurement values using the MannWhitney U test. All statistical analyses were performed using SPSS software Version 19 (IBM Corp., Armonk, NY, USA). $P$ values less than 0.05 were considered statistically significant.

\section{RESULTS}

The sociodemographic and clinical features of the patients were summarized in Table 1.

Table 1. Demographic parameters of the participants $(n=48)$.

\begin{tabular}{lccc}
\hline \multicolumn{1}{c}{ Parameters } & $\begin{array}{c}\text { Stage 1-2 } \\
\text { CMP } \\
(\mathrm{n}: 24)\end{array}$ & $\begin{array}{c}\text { Stage 3-4 } \\
\text { CMP } \\
(\mathrm{n}: 24)\end{array}$ & $\mathrm{p}$ value \\
\hline $\begin{array}{l}\text { Age (year), } \\
\text { mean (SD) }\end{array}$ & $33.8 \pm 5.8$ & $48.8 \pm 7.8$ & $<0,001$ \\
$\begin{array}{l}\text { BMI(Kg/m2),mean } \\
\text { (SD) }\end{array}$ & $28.6 \pm 4.6$ & $31.8 \pm 9.3$ & 0.475 \\
$\begin{array}{l}\text { Pain duration, } \\
\text { month, mean (SD) }\end{array}$ & $4 \pm 1$ & & \\
\hline $\begin{array}{l}\text { CMP: chondromalacia patellae, BMI: Body mass index, SD: standard } \\
\text { deviation } \\
\text { Data are presented as mean or number (n); }\end{array}$ & & \\
\end{tabular}


There was 13 male and 11 female patients in the early stage CMP group, 5 male and 19 female patients in the late stage CMP group. A comparison between the groups showed significantly higher mean age and duration of pain in patients with advanced stage disease $(\mathrm{p}<0.001)$. BMI values did not differ significantly between the groups $(\mathrm{p}=0.475)$.

Table 2 shows the results of the physical examination. Clark's test, patellar compression test and knee flexion angle were significantly higher in patients with early stage disease than those with advanced stage disease. $(p<0.05)$

Table 2. The physical examination parameters.

\begin{tabular}{|c|c|c|c|}
\hline $\begin{array}{l}\text { Positive physical } \\
\text { examination value }\end{array}$ & $\begin{array}{l}\text { Stage 1-2 } \\
\text { CMP } \\
(\mathrm{n}: 24)\end{array}$ & $\begin{array}{l}\text { Stage } 3-4 \\
\text { CMP } \\
(\mathrm{n}: 24)\end{array}$ & $\mathrm{p}$ \\
\hline
\end{tabular}

\begin{tabular}{llll} 
Clark & $15(62.5)$ & $21(87.5)$ & $0.046 *$ \\
Patellar compression & $15(62.5)$ & $21(87.5)$ & $0.046 *$ \\
Patellar tilt & $11(45.8)$ & $24(66.6)$ & $0.146 *$ \\
J finding & $7(29.1)$ & $9(37.5)$ & $0.540 *$ \\
Knee flexion measurement & $113.7 \pm 11.6$ & $96.5 \pm 8.2$ & $<0,001 * *$ \\
\hline
\end{tabular}

Data are presented as $\mathrm{n}(\%)$ or median (min-max);

CMP: chondromalacia patellae

*Chi square test

**Mann-Whitney U test

There were no significant differences between the groups in terms of the trochlear sulcus angle, sulcus depth, and lateral patellofemoral angle $(\mathrm{p}>0.05)$ (Table 3). Based on a trochlear sulcus angle of greater than 140 degrees, trochlear hypoplasia was identified in 8 subjects with early stage disease and 5 subjects with advanced stage disease. When a sulcus depth of $5 \mathrm{~mm}$ or less was used as a criterion, 6 patients with early stage disease and 5 patients with advanced stage disease were found to have trochlear hypoplasia. The corresponding figures based on a patellofemoral angle measurement of 8 degrees or less were 13 and 16, respectively. The two groups were not significantly different with regard to patellar translation and Insall-Salvati index values ( $p>0.05$ )
Table 3. Magnetic resonance imaging measurements and function level.

\begin{tabular}{|c|c|c|c|}
\hline Parameters value & $\begin{array}{l}\text { Stage } 1-2 \\
\text { CMP }\end{array}$ & $\begin{array}{l}\text { Stage 3-4 } \\
\text { CMP }\end{array}$ & $\mathrm{p}$ \\
\hline Sulcus angle (degree) & $138.9 \pm 8.9$ & $137.9 \pm 7.5$ & $0.508 *$ \\
\hline Sulcus depth (mm) & $5.3 \pm 1.3$ & $5.4 \pm 1.2$ & $0.819 *$ \\
\hline $\begin{array}{l}\text { Lateral patellofemoral angle } \\
\text { (degree) }\end{array}$ & $6.3 \pm 4.3$ & $5.1 \pm 5.1$ & $0.342 *$ \\
\hline Patellar translation (mm) & $4.1 \pm 3.2$ & $2.7 \pm 3.2$ & $0.277^{*}$ \\
\hline Install-Salvati index & $1.1 \pm 0.1$ & $1.2 \pm 0.1$ & $0.193 *$ \\
\hline WOMAC & $43.9 \pm 16$ & $70.2 \pm 10.5$ & $\mathrm{p}<0,001 * *$ \\
\hline Patella alta & $3(12.5)$ & $4(16.6)$ & \\
\hline Patella baja & $5(20.8)$ & $4(16.6)$ & \\
\hline \multicolumn{4}{|c|}{$\begin{array}{l}\text { CMP: chondromalacia patellae, WOMAC: Western Ontario and McMaster } \\
\text { Universities Arthritis Index } \\
\text { Data are presented as mean or number }(\mathrm{n}) \\
\text { *Mann-Whitney U test } \\
{ }_{* *} \text { Chi square test }\end{array}$} \\
\hline
\end{tabular}

In terms of patellar translation, 7 patients with early stage disease and 12 patients with advanced stage disease had a value below $8 \mathrm{~mm}$, suggestive of patellar subluxation. Eight patients with early stage disease and 13 patients with advanced stage disease had an Insall-Salvati index that was not in the normal range, with abnormal positioning of the patella. Patella alta and baja were determined in 3 and 5 patients with early stage disease, respectively. In patients with advanced stage disease, there were 4 patients with patella alta and 4 patients with patella baja. (Table 3 ).

A comparison of WOMAC scores showed significantly higher values among patients with advanced stage disease than those with early stage disease $(p<0.001)$ (Table 3$)$.

\section{DISCUSSION}

In the current study, although early and advanced stage disease groups were not significantly different in terms of patellar translation and lateral patellofemoral angle, both parameters were lower in those with advanced stage CMP. Patients with early or advanced stage CMP did not differ significantly with regard to sulcus depth and trochlear sulcus angle. The observed frequency of patella alta $(16.6 \%)$ and patella baja (16.6\%) was lower as compared to previous reports. However, the significant difference between the study groups in terms of functionality parameters was consistent with the published data, and patients with advanced CMP had higher scores. Compared with previous reports, higher rates of positivity were observed for physical exam tests among patients with advanced CMP in our study ${ }^{17}$, except for the J sign. These 
findings suggest that physical examination may play a more prominent role in the diagnosis of advanced stage CMP, and this assumption may be tested in larger patient series.

The patellofemoral joint is a complex anatomical structure with high level of functionality and complicated biomechanical properties. The anatomy of the patellofemoral joint is thought to play a determinative role in problems involving the anterior knee. Thus, a sound understanding of the anatomy and biomechanical properties of this joint is critical for the diagnosis and treatment of conditions associated with patellofemoral pain. ${ }^{18-20}$ Among all anatomical structures of the knee joint, patellofemoral joint represents an anatomical site that may lead to a high level of discordance between subjective complaints and objective clinical and imaging findings. While only minimal objective findings may be detected in some patients with severe complaints, symptoms may be relatively limited despite significant clinical and imaging findings in some others. This has led to the utilization of various clinical, radiological and etiological parameters for the diagnosis of this disorder. Recommendations for the diagnosis and management of CMP should not only be objective, but should also have clinical utility. Magnetic resonance imaging provides high-resolution, multi-planar images of osseous, chondral, and soft tissue elements in the knee, with avoidance from radiation as in the computed tomography. ${ }^{21-22}$ Although a variety of physical examination methods for CMP have been proposed in the literature, these tests are generally associated with low diagnostic sensitivity and no specific physical exam methods have been described in the literature. ${ }^{23-24}$

Trochlear dysplasia, which was examined using magnetic resonance imaging in our study, is characterized by the proximal flattening of the trochlear sulcus together with reduced distal concavity, leading to lateral displacement of the patella during flexion. Ultimately, this may result in instability, patellar dislocation, and loss of cartilage in the patellofemoral joint. Basically, a diagnosis of trochlear dysplasia can be reliably established using trochlear depth and trochlear sulcus angle measurements. ${ }^{25}$ Some previous studies reported a close link between CMP and decreased trochlear depth and increased trochlear sulcus angle 26 ${ }^{27}$ while others failed to observe a similar correlation. ${ }^{28}$
Although reduced patellar translation and decreased lateral patellofemoral angle have been reported to predispose individuals to Hoffa's fat pad impingement syndrome, their relationship with CMP has not been mentioned. ${ }^{29}$

Also, increased Install Salvati index value and presence of patella alta were reported to increase the risk of $\mathrm{CMP}^{30-31}$, in which case a high positioned patella is reaches onto the femur with a delay during flexion, leading to excessive lateral movement of the patella. ${ }^{32}$ Experiments on mechanical models showed that patella alta is associated with decreased joint contact as well as an abnormal increase in the surface forces between patella and trochlea. ${ }^{25}$ On the other hand, reports on the association of both patella alta and baja with CMP are somewhat controversial. $^{33}$

Due to the incomplete congruency between patella and trochlea, the stability of the patellofemoral joint is dependent on the static and dynamic soft tissue anatomy. Patellar tendon, joint capsule, and ligamentous structures represent the static stability, while muscles provide the dynamic stability. We believe that consideration of only static elements of the joint may represent a potential explanation for the absence of a concensus-based radiodiagnostic algorithm.

It should also be borne in mind that the pathology in CMP not only involves an alignment disorder, but also is affected by the neural mechanisms, with impaired sense of joint position and proprioception developing over time. ${ }^{34-}$ 35

Limitations of our study include the absence of an arthroscopic CMP diagnosis, lack of healthy controls for comparison, and inadequate number of patients precluding comparisons between stage 1-2-3-4 separately.

Our study showed that more advanced stages of CMP is associated with reduced patient functionality. Results of all physical examination tests except for J sign were also more remarkable in CMP patients. On the other hand, early and advanced stage CMP patients did not differ significantly with regard to magnetic resonance parameters. A better understanding on the difference in mechanisms involved in the patellofemoral anatomy as well as the absence of a correlation with the stage of CMP may allow more 
objective rehabilitation to be implemented. We believe that further studies with larger sample size and dynamic assessment of the joint biomechanics may shed more light on this subject.

\section{Conflicts of Interest}

The authors declare that they have no conflict of interest.

\section{REFERENCES}

1. Özkoç G. Patellar Kondromalazi. TOTBİD Dergisi. 2012;11(4):335-338

2. Dos Santos RL, Souza ML, Dos Santos FA. Neuromuscular electric stimulation in patellofemoral dysfunction: riterature review. Acta Ortop Bras. 2013;21(1):52-58.

3. Hartley A, Robinson MM. Practical Joint Assessment: Lower Quadrant A Sports Medicine Manual. 2. Ed. USA;Mosby Inc; 1995.

4. Arnheim DD, Bonacci JA, Kauth WO, Prentice WE. Principles of athletic training. 11th Edition. USA;McGrawHill;2002.

5. Doberstein ST, Romeyn RL, Reineke DM. The diagnostic value of the Clarke sign in assessing chondromalacia patella. J Athl Train. 2008;43(2):190-196.

6. Demehri S, Thawait GK, Williams AA, et al. Imaging characteristics of contralateral asymptomatic patellofemoral joints in patients with unilateral instability. Radiology. 2014;273(3):821-830.

7. Thomas S, Rupiper D, Stacy GS. Imaging of the patellofemoral joint. Clin Sports Med. 2014;33(3):413436.

8. Merchant AC. Classification of patellofemoral disorders. Arthroscopy. 1988;4(4):235-240.

9. Horton MG, Hall TL. Quadriceps femoris muscle angle: normal values and relationships with gender and selected skeletal measures. Phys Ther. 1989;69(11):897-901.

10. Aglietti P, Buzzi R, Insall JN. Surgery of the Knee. 2. Ed. USA;Churchill Living-stone; 1993.

11. Bakhtiary AH, Fatemi E. Open versus closed kinetic chain exercises for patellar chondromalacia. Br J Sports Med. 2008;42(2):99-102.

12. Biedert RM, Sanchis-Alfonso V. Sources of anterior knee pain. Clin Sports Med. 2002;21(3):335-347.

13. Aydoğdu S. Patellofemoral eklem hastalıklarının sinıflandirması. TOTBID Dergisi. 2012;11(4):284-289.

14. Stratford P, Kennedy D, Woodhouse L, Spadoni G. Measurement properties of the WOMAC LK 3.1 pain scale. Osteoarthritis and cartilage. 2007;15(3):266-272.

15. Chhabra A, Subhawong TK, Carrino JA. A systematised MRI approach to evaluating the patellofemoral joint. Skeletal Radiol. 2011;40(4):375-387.

16. Koskinen SK, Taimela S, Nelimarkka O, Komu M, Kujala UM. Magnetic resonance imaging of patellofemoral relationships. Skeletal Radiol. 1993;22(8):403-410.

17. Aysin IK, Askin A, Mete BD, Guvendi E, Aysin M, Kocyigit H. Investigation of the Relationship between Anterior Knee Pain and Chondromalacia Patellae and
Patellofemoral Malalignment. Eurasian J Med. 2018;50(1):28-33

18. Saddik D, McNally E, Richardson M. MRI of Hoffa's fat pad. Skeletal Radiol. 2004;33(8):433-444.

19. Hoffa A. The influence of the adipose tissue with regard to the pathology of the knee joint. J Am Med Assoc. 1904;43(12):795-796.

20. Davies AP, Costa ML, Donnell ST, Glasgow MM, Shepstone L. The sulcus angle and malalignment of the extensor mechanism of the knee. J Bone Joint Surg 2000;82(8):1162-1166.

21. Baysal O, Baysal B, Altay Z, Yologlu S. Comparison of MRI graded cartilage and MRI based volume measurement in knee osteoarthritis. Swiss Med Wkly. 2004;134(1920):283-288.

22. Yang B, Tan H, Yang L, Dai G, Guo BJO. Correlating anatomy and congruence of the patellofemoral joint with cartilage lesions. Orthopedics. 2009;32(1):20.

23. Dixit S, Difiori JP, Burton M, Mines B. Management of patellofemoral pain syndrome. Am Fam Physician. 2007;75(2):194-202.

24. Fredericson M, Yoon K. Physical examination and patellofemoral pain syndrome. Am J Phys Med Rehabil. 2006;85(3):234-243.

25. Feller JA, Amis AA, Andrish JT, Arendt EA, Erasmus PJ, Powers CM. Surgical biomechanics of the patellofemoral joint. Arthroscopy. 2007;23(5):542-553.

26. Ali SA, Helmer R, Terk MR. Analysis of the patellofemoral region on MRI: association of abnormal trochlear morphology with severe cartilage defects. AJR Am J Roentgenol. 2010;194(3):721-727.

27. Tuna BK, Semiz-Oysu A, Pekar B, Bukte Y, Hayirlioglu A. The association of patellofemoral joint morphology with chondromalacia patella: a quantitative MRI analysis. Clin Imaging. 2014;38(4):495-498.

28. Endo Y, Schweitzer ME, Bordalo-Rodrigues M, Rokito AS, Babb JS. MRI quantitative morphologic analysis of patellofemoral region: lack of correlation with chondromalacia patellae at surgery. AJR Am J Roentgenol. 2007;189(5):1165-1168.

29. Jibri Z, Martin D, Mansour R, Kamath SJSr. The association of infrapatellar fat pad oedema with patellar maltracking: a case-control study. Skeletal Radiol. 2012;41(8):925-931.

30. Houghton KM. Review for the generalist: evaluation of anterior knee pain. Pediatr Rheumatol Online J. 2007;5(8).

31. Kalichman L, Zhang Y, Niu J, et al. The association between patellar alignment and patellofemoral joint osteoarthritis features - an MRI study. Rheumatology. 2007;46(8):1303-1308.

32. Simmons JE, Cameron JC. Patella alta and recurrent dislocation of the patella. Clin Orthop Relat Res. 1992;(274):265-269.

33. Kettunen JA, Visuri T, Harilainen A, Sandelin J, Kujala UM. Primary cartilage lesions and outcome among subjects with patellofemoral pain syndrome. Knee Surg Sports Traumatol Arthrosc. 2005;13(2):131-134.

34. Fulkerson JP, Tennant R, Jaivin JS, Grunnet M. Histologic evidence of retinacular nerve injury associated with patellofemoral malalignment. Clin Orthop Relat Res. 1985;(197):196-205.

35. Jensen R, Hystad T, Kvale A, Baerheim A. Quantitative sensory testing of patients with long lasting patellofemoral pain syndrome. Eur J Pain. 2007;11(6):665-676. 